\title{
Asian dust storm observed at a rural mountain site in southern China: chemical evolution and heterogeneous photochemistry
}

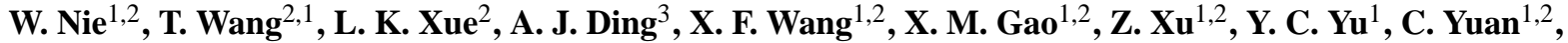

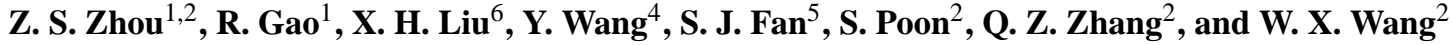 \\ ${ }^{1}$ Environment Research Institute, Shandong University, Jinan, China \\ ${ }^{2}$ Department of Civil and Environmental Engineering, The Hong Kong Polytechnic University, Hong Kong, China \\ ${ }^{3}$ Institute for Climate and Global Change Research, Nanjing University, Nanjing, China \\ ${ }^{4}$ School of Environmental Science and Engineering, Shandong University, Jinan, China \\ ${ }^{5}$ School of Environmental Science and Engineering, Sun Yat-Sen University, Guangzhou, China \\ ${ }^{6}$ College of Environmental Science and Engineering, Ocean University of China, Qingdao, China
}

Correspondence to: T. Wang (cetwang@polyu.edu.hk)

Received: 12 July 2012 - Published in Atmos. Chem. Phys. Discuss.: 2 August 2012

Revised: 20 November 2012 - Accepted: 30 November 2012 - Published: 17 December 2012

\begin{abstract}
Heterogeneous processes on dust particles are important for understanding the chemistry and radiative balance of the atmosphere. This paper investigates an intense Asian dust storm episode observed at Mount Heng (1269 m a.s.1.) in southern China on 24-26 April 2009. A set of aerosol and trace gas data collected during the study was analyzed to investigate their chemical evolution and heterogeneous photochemistry as the dust traveled to southern China. Results show that the mineral dust arriving at Mt. Heng experienced significant modifications during transport, with large enrichments in secondary species (sulfate, nitrate, and ammonium) compared with the dust composition collected at an upwind mountain top site (Mount Hua). A photochemical age "clock" ( $\left.-\log _{10}\left(\mathrm{NO}_{\mathrm{x}} / \mathrm{NO}_{\mathrm{y}}\right)\right)$ was employed to quantify the atmospheric processing time. The result indicates an obvious increase in the abundance of secondary water-soluble ions in dust particles with the air mass atmospheric processing time. Based on the observations, a 4-stage evolution process is proposed for carbonate-containing Asian dust, starting from fresh dust to particles coated with hydrophilic and acidic materials. Daytime-enhanced nitrite formation on the dust particles was also observed, which indicates the recent laboratory result of the $\mathrm{TiO}_{2}$ photocatalysis of $\mathrm{NO}_{2}$ as a potential source of nitrite and nitrous acid.
\end{abstract}

\section{Introduction}

Mineral dust is injected into the atmosphere under specific meteorological conditions in deserts or semiarid areas, generating dust storms. In East Asia, the Taklimakan Desert in western China and the Gobi Desert in Mongolia and northern China are the two major source regions of dust, with annual emissions between $100 \mathrm{Mt} \mathrm{yr}^{-1}$ and $460 \mathrm{Mt} \mathrm{yr}^{-1}$ (Laurent et al., 2006). Upon entering the atmosphere, especially when transported over heavily polluted regions, the chemical and surface nature of mineral dust particles undergo significant changes, in turn influencing a number of atmospheric processes (Zhuang et al., 1992; Usher et al., 2003; Formenti et al., 2011, and the references therein).

In the past few decades, several large field campaigns (e.g., TRACP, ACE-Asia and INTEX-B) have studied the atmospheric processes of Asian dust (Jocob et al., 2003; Arimoto et al., 2006; Singh et al., 2009). The evolutionary processes of dust particles during their eastward transport to the western Pacific have been already investigated in northeast Asia. These studies have significantly improved understanding of the heterogeneous reactions between Asian pollution and mineral dust. Sullivan et al. (2007a) found that nitrate tended to accumulate on calcium-rich dust, while sulfate tended to accumulate on aluminosilicate-rich dust. $\mathrm{Li}$ and Shao (2009) demonstrated nitrate being coated onto dust particles. The direct uptake of chlorine on dust particles by 
heterogeneous reaction with $\mathrm{HCl}$ was clearly verified by Sullivan et al. (2007b). Sullivan and Prather (2007) observed internally mixed organic dicarboxylic acid (DCA) with dust particles and proposed a mechanism of heterogeneous oxidation of DCA on the surface of Asian dust. To our knowledge, there have been very few studies of the chemical evolution of Asian dust during its transport to southern China, where the dust is subject to higher temperature, higher humidity, and possibly different emissions compared with eastward transport.

Heterogeneous reactions on dust particles have been extensively investigated, and most previous studies have focused on nighttime chemistry (Usher et al., 2003). Photoinduced/enhanced reactions of some reactive gases on dust particles have recently been demonstrated by laboratory studies (Cwiertny et al., 2008 and the references therein). Nicolas et al. (2009) observed photo-enhanced $\mathrm{O}_{3}$ decomposition on mimic mineral dust particles of $\mathrm{TiO}_{2} / \mathrm{SiO}_{2}$ mixtures; Ndour et al. (2008) detected the photo-enhanced uptake of $\mathrm{NO}_{2}$ on both $\mathrm{TiO}_{2} / \mathrm{SiO}_{2}$ mixed particles and real Saharan and Arizona dust particles. The latter reaction received great attention because it may be a missing source of daytime nitrous acid (HONO). However, the extent of that reaction has not been observed in the real atmosphere.

As part of China's National Basic Research Project on acid rain, a comprehensive field campaign was conducted from March to May 2009 at Mt. Heng in Hunan province, southern China (Fig. 1), during which an intense dust storm was observed on 24-26 April. The aim of the specific work is to investigate the impact of this Asian dust storm on the atmospheric chemistry at rural and remote mountain regions in southern China. Special attention is given to the chemical evolution of the dust by comparison with the aerosol composition concurrently observed at another mountain site near the dust source region (Wang et al., 2011), as well as the role of heterogeneous photochemistry in the production of nitrite. The general features and transport pathway of this dust storm are described first. The chemical evolution of the dust particles during transport from Mt. Hua to Mt. Heng is then investigated. A photochemical age "clock" $\left(-\log _{10}\left(\mathrm{NO}_{\mathrm{x}} / \mathrm{NO}_{\mathrm{y}}\right)\right.$ is employed to examine the changes in the major secondary water-soluble ions with the atmospheric processing time. The evidence of the daytime production of nitrite on dust particles is also presented, and its possible mechanism and potential contribution to the gas-phase HONO is discussed.

\section{Experimental methodologies}

\subsection{Site description}

Mt. Heng is situated in Hunan Province, southern China, and is approximately $500 \mathrm{~km}$ and $900 \mathrm{~km}$ from the South China Sea and the East China Sea, respectively (Figs. 1a and 2). The field campaign was conducted at a meteorological station at
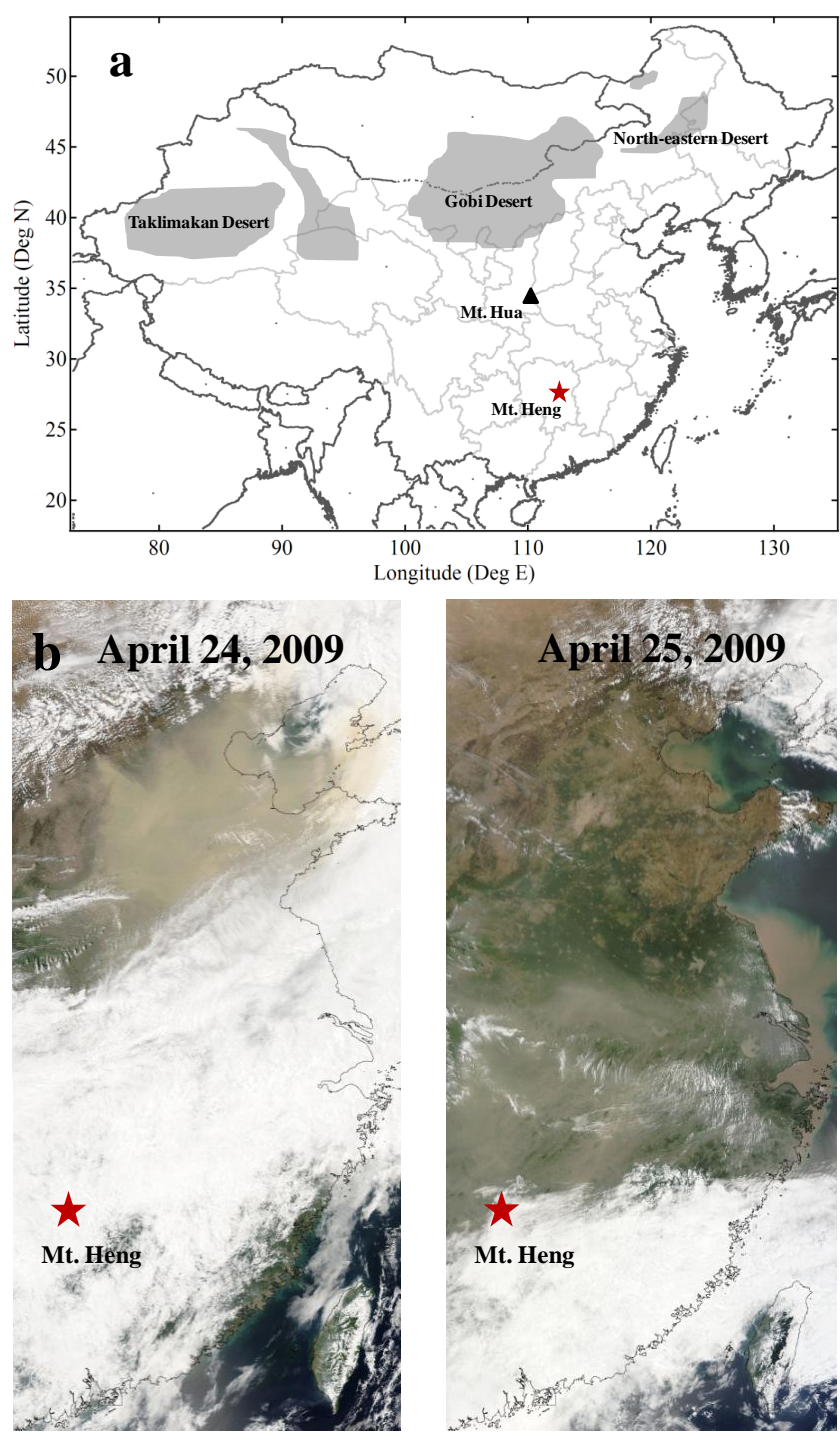

Fig. 1. (a) Map showing Mt. Heng and Mt. Hua. The major deserts in East Asia are marked by the shadows in the map. (b) MODIS true-color imagery of eastern China on 24 and 25 April 2009.

the summit of Mt. Heng $\left(27^{\circ} 18^{\prime} \mathrm{N}, 112^{\circ} 42^{\prime} \mathrm{E}, 1269 \mathrm{~m}\right.$ a.s.1.). There are a few temples and a road around the mountain top of Mt. Heng. Emissions from incense burning and traffic may occasionally affect the trace gas and aerosol measurements at the site. There are few other local emission sources around the measurement site. The closest cities are Hengyang and Xiangtan, which are approximately $50 \mathrm{~km}$ to the south and $70 \mathrm{~km}$ to the north, respectively.

\subsection{Field campaign, sample collection and measurement techniques}

The field campaign covered a 3-month period from March to May 2009. A comprehensive suite of trace gases, aerosols, and rain and cloud water samples was measured/collected 


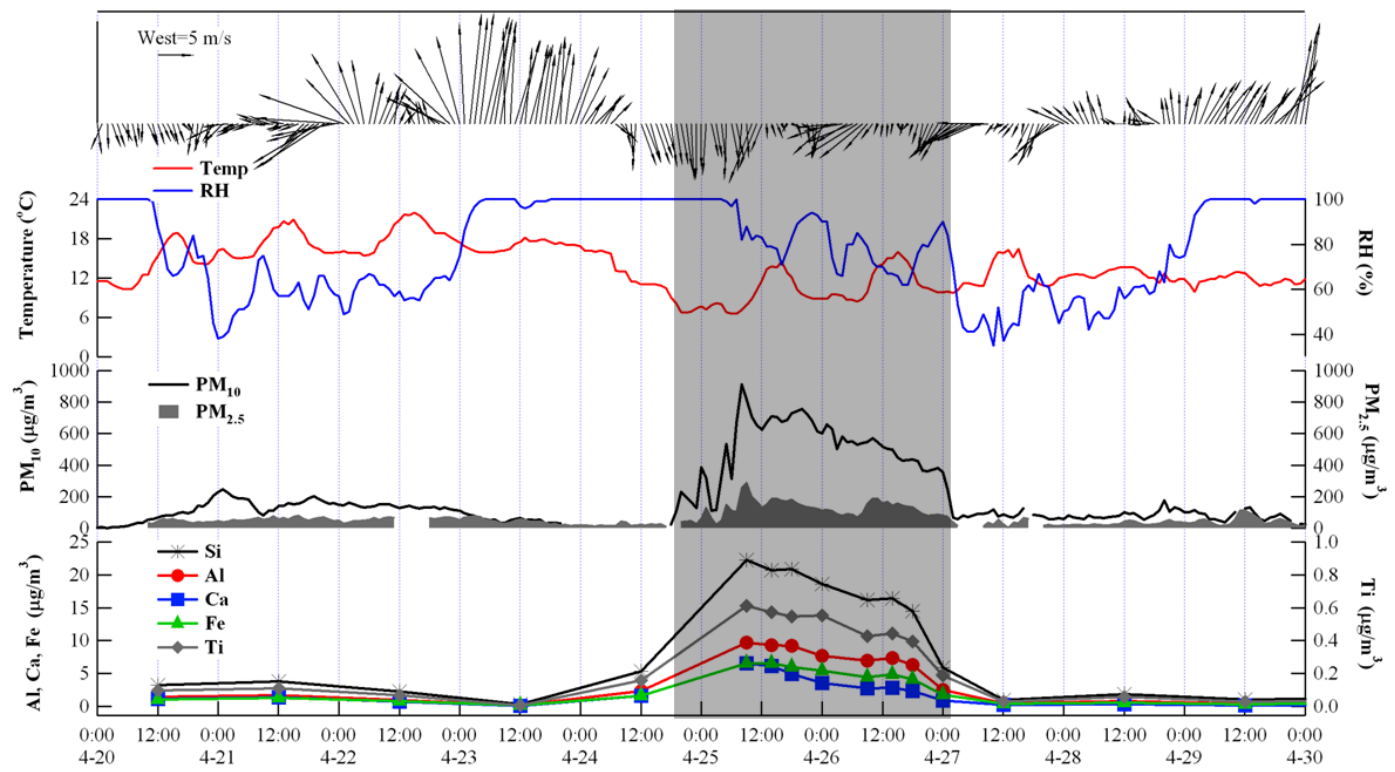

Fig. 2. Temporal variations of $\mathrm{PM}_{10}, \mathrm{PM}_{2.5}$, mineral elements ( $\left.\mathrm{Si}, \mathrm{Al}, \mathrm{Ca}, \mathrm{Fe}, \mathrm{Ti}\right)$ in $\mathrm{PM}_{2.5}$ and meteorological parameters at $\mathrm{Mt}$. Heng during 20 to 29 April 2009.

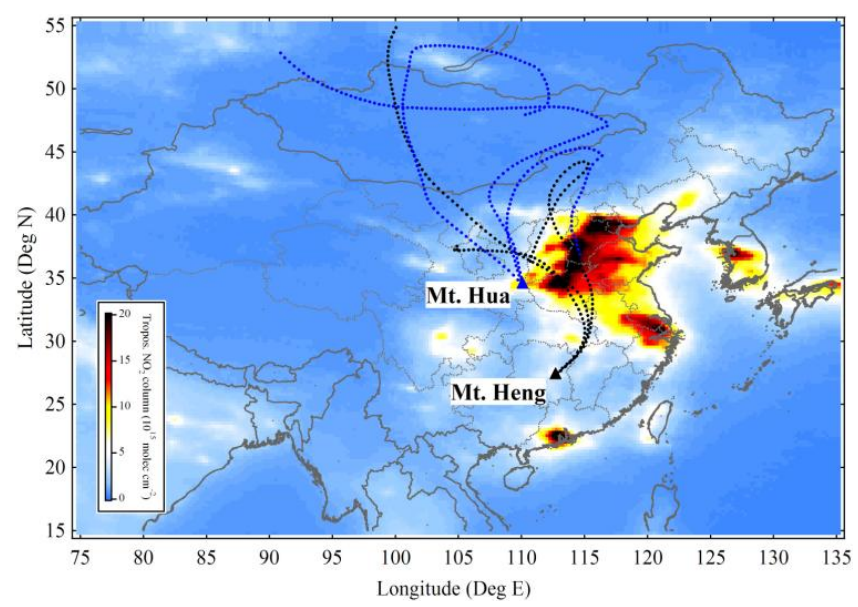

Fig. 3. The 72-h backward trajectories for the dust event at Mt. Hua and Mt. Heng. The $\mathrm{NO}_{2}$ column data from GOME and SCIAMACHY (averaged over 1996-2007, Wang et al., 2009) are shown in the shaded areas.

(Sun et al., 2010; Gao et al., 2012; Zhou et al., 2012). The present study is focused on the dust storms observed during 20-29 April 2009 (Fig. 3). The dataset employed in this paper includes continuous data of $\mathrm{SO}_{2}, \mathrm{NO}_{\mathrm{x}}, \mathrm{NO}_{\mathrm{y}}, \mathrm{PM}_{2.5}$, $\mathrm{PM}_{10}$ and black carbon (BC); filter-based element data of $\mathrm{Si}$, $\mathrm{Al}, \mathrm{Fe}, \mathrm{Ca}$ and $\mathrm{Ti}$ in $\mathrm{PM}_{2.5}$ and $\mathrm{Al}$ in TSP; and size-resolved water-soluble ions $\left(\mathrm{SO}_{4}^{2-}, \mathrm{NO}_{3}^{-}, \mathrm{NO}_{2}^{-}, \mathrm{NH}_{4}^{+}, \mathrm{Ca}^{2+}\right)$.

Measurements of trace gases were done as follows: $\mathrm{SO}_{2}$ was measured with a pulsed UV fluorescence analyzer (TEI model $43 \mathrm{C}$ ); $\mathrm{NO}_{\mathrm{y}}$ (defined as $\mathrm{NO}_{\mathrm{x}}$ and its oxidation products and intermediates) was converted to NO with heated molybdenum oxide $(\mathrm{MoO})$ and measured with a chemiluminescence analyzer (TEI model $42 \mathrm{CY}$ ); $\mathrm{NO}_{2}$ was converted to $\mathrm{NO}$ with a blue light converter (Meteorologieconsult $\mathrm{GmbH}$ ) and measured with another NO analyzer (TEI model 42I). The $\mathrm{NO}_{2}$ conversion efficiencies, determined by the method of gas-phase titration, were approximately $40 \%$ on average during the whole sampling period. The calibration methods followed those reported in Wang et al. (2001). In this study, hourly-averaged data were employed for all the gaseous species and the uncertainties were estimated to be within $\pm 10 \%$ (Wang et al., 2001, 2003).

Sampling and analysis of aerosols were done as follows: $\mathrm{PM}_{2.5}$ and $\mathrm{PM}_{10}$ mass concentrations were continuously measured with a tapered element oscillating microbalance (TEOM, Thermo Electron Corporation, East Greenbush, NY, USA). BC was measured using an Aethalometer (Magee Scientific, Berkeley, California, USA, Model AE-21) at a wavelength of $880 \mathrm{~nm}$. $\mathrm{PM}_{2.5}$ filter samples were collected using a four-channel particle sampler (Thermo Andersen Chemical Speciation Monitor, RAAS2.5-400, Thermo Electron Corporation) with Teflon filters (Teflon ${ }^{\text {TM }}, 2 \mu \mathrm{m}$ pore size and $47 \mathrm{~mm}$ diameter, Pall Inc.) at a flow rate of 16.7 liters per minute (LPM) (Wu and Wang, 2007). Total Suspended Particulates (TSP) samples were collected using medium-volume air samplers (TH-105C, Wuhan Tianhong Intelligent Instrument Corp. Co., Ltd., China) at flow rate of $100 \mathrm{LPM}$ on glass fiber filters (GFFs, $90 \mathrm{~mm}$ in diameter). The size-resolved particles were collected with a MicroOrifice Uniform Deposit Impactor (MOUDI, MSP Company) with aluminum substrates (MSP Company) at a flow rate of $30 \mathrm{LPM}$ (Nie et al., 2010). The impactor collected 
Table 1. Comparison of chemical species in non-dust and dust storm periods during the Mt. Heng study.

\begin{tabular}{|c|c|c|c|c|c|c|}
\hline \multirow[t]{2}{*}{ Species } & \multicolumn{2}{|c|}{ Dust } & \multicolumn{2}{|c|}{ Non-dust } & \multirow{2}{*}{ PM size } & \multirow{2}{*}{ Sampling instruments } \\
\hline & Concentrations & Sample numbers & Concentrations & Sample numbers & & \\
\hline $\mathrm{PM}_{10}\left(\mu \mathrm{g} \mathrm{m}^{-3}\right)$ & $502 \pm 196$ & 55 & $45.6 \pm 32.4$ & 1195 & $\mathrm{PM}_{10}$ & TEOM \\
\hline $\mathrm{PM}_{2.5}\left(\mu \mathrm{g} \mathrm{m}^{-3}\right)$ & $125 \pm 55$ & 54 & $32.3 \pm 22.6$ & 1273 & $\mathrm{PM}_{2.5}$ & TEOM \\
\hline $\mathrm{PM}_{2.5} / \mathrm{PM}_{10}$ & $0.25 \pm 0.08$ & 54 & $0.63 \pm 0.23$ & 621 & & TEOM \\
\hline $\mathrm{Si}\left(\mu \mathrm{g} \mathrm{m}^{-3}\right)$ & $18.5 \pm 2.9$ & 7 & $1.1 \pm 0.6$ & 7 & $\mathrm{PM}_{2.5}$ & RAAS \\
\hline $\mathrm{Al}\left(\mu \mathrm{g} \mathrm{m}^{-3}\right)$ & $8.1 \pm 1.3$ & 7 & $0.47 \pm 0.25$ & 7 & $\mathrm{PM}_{2.5}$ & RAAS \\
\hline $\mathrm{Fe}\left(\mu \mathrm{g} \mathrm{m}^{-3}\right)$ & $5.4 \pm 1.0$ & 7 & $0.39 \pm 0.17$ & 7 & $\mathrm{PM}_{2.5}$ & RAAS \\
\hline $\mathrm{Ca}\left(\mu \mathrm{g} \mathrm{m}^{-3}\right)$ & $4.2 \pm 1.7$ & 7 & $0.20 \pm 0.10$ & 7 & $\mathrm{PM}_{2.5}$ & RAAS \\
\hline $\operatorname{Ti}\left(\mu \mathrm{g} \mathrm{m}^{-3}\right)$ & $0.5 \pm 0.1$ & 7 & $0.03 \pm 0.02$ & 7 & $\mathrm{PM}_{2.5}$ & RAAS \\
\hline Sulfate $\left(\mu \mathrm{g} \mathrm{m}^{-3}\right)$ & $20.0 \pm 3.9$ & 4 & $13.8 \pm 6.1$ & 21 & TSP & MOUDI \\
\hline Nitrate $\left(\mu \mathrm{g} \mathrm{m}^{-3}\right)$ & $16.9 \pm 3.4$ & 4 & $8.2 \pm 5.4$ & 21 & TSP & MOUDI \\
\hline $\mathrm{NO}_{\mathrm{y}}(\mathrm{ppbv})$ & $6.5 \pm 2.1$ & 55 & $3.7 \pm 5.4$ & 1505 & & $42 \mathrm{CY}$ \\
\hline $\mathrm{SO}_{2}(\mathrm{ppbv})$ & $4.2 \pm 2.2$ & 55 & $2.1 \pm 2.4$ & 1396 & & $43 \mathrm{C}$ \\
\hline $\mathrm{NO}_{\mathrm{X}}(\mathrm{ppbv})$ & $2.1 \pm 0.7$ & 55 & $1.0 \pm 0.8$ & 671 & & $42 \mathrm{I}$ \\
\hline
\end{tabular}

particles in nine size ranges: $>18 \mu \mathrm{m}$ (inlet), $10-18 \mu \mathrm{m}, 5.6-$ $10 \mu \mathrm{m}, 3.2-5.6 \mu \mathrm{m}, 1.8-3.2 \mu \mathrm{m}, 1-1.8 \mu \mathrm{m}, 0.56-1 \mu \mathrm{m}, 0.32-$ $0.56 \mu \mathrm{m}$, and $0.18-0.32 \mu \mathrm{m}$. Submicron particle $\left(\mathrm{PM}_{<1}\right)$ concentrations are calculated by the sum of last three stages. Supermicron particle $\left(\mathrm{PM}_{>1}\right)$ concentrations are calculated by the sum of first five stages. The sampled filters were stored at $-5^{\circ} \mathrm{C}$ in order to minimize artifacts. In this paper, the discussions on the chemical evolution of mineral dust particles focus on the supermicron dust particles $\left(\mathrm{PM}_{>1}\right)$.

The elements in $\mathrm{PM}_{2.5}$ and TSP were measured using Xray fluorescence (XRF) and inductively coupled plasma mass spectrometry (ICP-MS), respectively. The water-soluble ions were analyzed using ion chromatography (IC) (Dionex 90) (Wu and Wang, 2007). The measurement uncertainties of water-soluble ions and elements were estimated to be $\pm 10 \%$ (Vecchi et al., 2008; Zhou et al., 2009). The evaporation loss of ammonium nitrate can be ignored due to the low ambient temperature $\left(<20^{\circ} \mathrm{C}\right.$, Fig. 2) (Nie et al., 2010). During the dust storm of 24-26 April, we collected four sets of sizeresolved aerosol samples using MOUDI: sample-I, sampleII, sample-III and sample-IV, with sample-I and sampleIII collected during daytime (08:00-20:00 LT) and sampleII and sample-IV at night (20:00-08:00 of next day, LT) (Fig. 5).

\section{Results and discussion}

\subsection{General description of the dust episodes}

Figure 2 shows the temporal variations of meteorological parameters, particle mass, and chemical species observed at Mt. Heng during 20-29 April 2009, including wind speed, wind direction, temperature, $\mathrm{RH}, \mathrm{PM}_{10}, \mathrm{PM}_{2.5}$, and major mineral elements ( $\mathrm{Si}, \mathrm{Al}, \mathrm{Ca}, \mathrm{Fe}, \mathrm{Ti}$ ) in $\mathrm{PM}_{2.5}$. During this period, a moderate dust storm was observed on 21-22
April, with hourly averaged $\mathrm{PM}_{10}$ and $\mathrm{PM}_{2.5}$ concentrations of $153 \mu \mathrm{g} \mathrm{m}^{-3}$ and $57 \mu \mathrm{g} \mathrm{m}^{-3}$, respectively. A more intense dust storm attacked the sampling site on 24-26 April, as highlighted by the shadow in Fig. 2, with the hourly averaged $\mathrm{PM}_{10}$ and $\mathrm{PM}_{2.5}$ concentrations reaching $502 \mu \mathrm{g} \mathrm{m}^{-3}$ and $125 \mu \mathrm{g} \mathrm{m}^{-3}$, respectively. Prevailing northerly winds occurred during the dust storm periods (Fig. 2). The second dust storm on 24-26 April was also observed at three other sites at Mt. Hua in the Shaanxi province of central China (Fig. 1a), Mt. Tai in the Shandong province of central-eastern China (Wang et al., 2011) and the island of Taiwan. This dust event was also clearly shown in the MODIS true-color image for 24 and 25 April (Fig. 1b). These observations indicate a large geographical region of southern and eastern China being influenced by this dust storm. Due to the significant particle loading and more extensive transport, the specific analysis is focused on the second dust storm event (24 to 26 April).

Table 1 compares a set of species/parameters measured in non-dust periods and dust storm periods (24-26 April), including $\mathrm{PM}_{10}, \mathrm{PM}_{2.5}, \mathrm{PM}_{2.5} / \mathrm{PM}_{10}$ ratio, mineral elements ( $\mathrm{Si}, \mathrm{Al}, \mathrm{Ca}, \mathrm{Fe}$ and $\mathrm{Ti}$ ) in $\mathrm{PM}_{2.5}$, sulfate and nitrate in TSP, $\mathrm{NO}_{\mathrm{y}}, \mathrm{NO}_{\mathrm{x}}$ and $\mathrm{SO}_{2}$. Compared to non-dust periods, all the species in the dust storm event showed higher concentrations: $\mathrm{PM}_{10}$ and mineral elements in $\mathrm{PM}_{2.5}$ increased by 10 20 fold; $\mathrm{PM}_{2.5} / \mathrm{PM}_{10}$ ratio decreased from 0.63 to 0.25 ; anthropogenic pollutants (sulfate, nitrate, $\mathrm{NO}_{\mathrm{y}}, \mathrm{SO}_{2}$ and $\mathrm{NO}_{\mathrm{x}}$ ) increased only moderately, by $0.4-1.2$ fold. These results reveal that the dust storm of 24-26 April brought to Mt. Heng high loading mineral dusts that had been mixed with moderate anthropogenic pollutants. Gao et al. (2012) have examined the size distributions of major water-soluble ions in nondust periods, which showed the presence of sulfate and ammonium as a single peak in the fine particle mode and nitrate as dual peaks in the fine and coarse mode. As to be shown 
(a) Sulfate

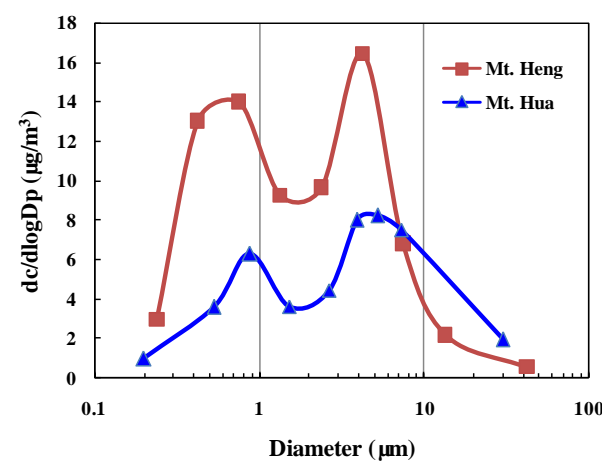

(c) Ammonium

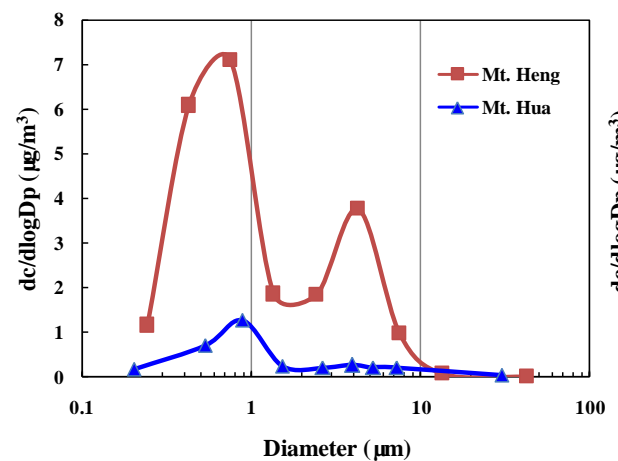

(b) Nitrate

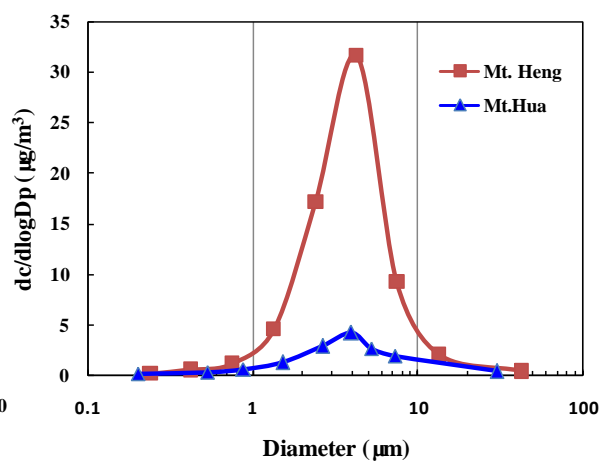

(d) Calcium

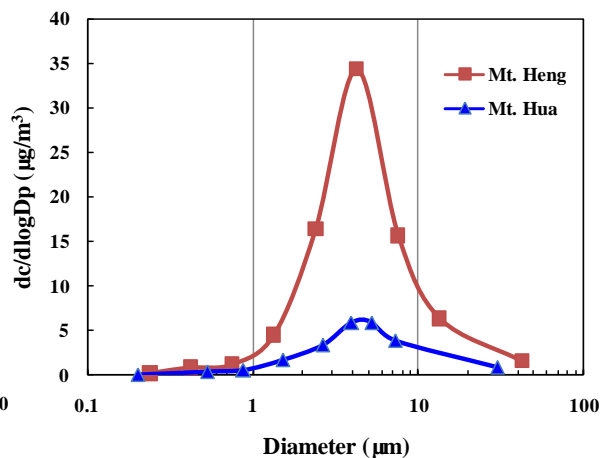

Fig. 4. Size distributions of (a) sulfate, (b) nitrate, (c) ammonium and (d) calcium at Mt. Hua and Mt. Heng during the dust event on 24-26 April.

in Sect. 3.2.1, during the dust storm of 24-26 April, the size distributions of these ions were significantly modified.

In order to characterize the origin and transport pathway of the air masses, a NOAA HYSPLIT4 model (Hybrid SingleParticle Lagrangian Integrated Trajectory) was employed to calculate 72-h backward trajectories arriving at Mt. Hua and Mt. Heng during the dust event of 24-26 April. As illustrated in Fig. 3a, the dust originating in the Gobi Desert moved southward and passed over central China (Shaanxi province), the North China Plain (Hebei province, Shanxi province and Henan province) and southern China (Hubei province and Hunan province) and is expected to travel farther to the South China Sea.

\subsection{Chemical evolution of mineral dust particles during transport}

\subsubsection{Comparison with samples collected near the dust source region}

The concurrent campaigns during the dust storm of 24-26 April at Mt. Hua (Wang et al., 2010) and Mt. Heng (this study) provide an opportunity to directly investigate the evolution of mineral dust particles from a near source region in the north to a southern mountainous area. Figure 4 illustrates the size distributions of four major water-soluble ions, including sulfate, nitrate, ammonium and calcium, at Mt. Hua (sample of 24 April) and Mt. Heng (sample of 25 April). The size distribution patterns of sulfate, nitrate and calcium at both mountain sites were similar: sulfate had a bimodal size distribution, with one peak in the submicron range and another larger peak in the supermicron range; nitrate and calcium showed single peaks in the coarse mode. For ammonium, the size distribution exhibited different patterns at the two sites, being unimodal at Mt. Hua, but bimodal at Mt. Heng. Compared with Mt. Hua, all four ions in the supermicron particles at Mt. Heng showed significant enhancement (Fig. 4): sulfate increased by approximately $56 \%$, but the other three ions were enhanced up to 5-7 times. The enrichments of water-soluble ions on dust particles at Mt. Heng can be generally attributed to the injection of anthropogenic emissions as the dust plumes passed over the polluted North China Plains (see Fig. 3).

The different degrees of enrichment for the different ions at Mt. Heng may be influenced by the relative abundance of $\mathrm{SO}_{2}, \mathrm{NO}_{\mathrm{x}}$ and $\mathrm{NH}_{3}$ in the atmosphere and the factors affecting their uptake/conversion on dust particles. Due to a higher hygroscopicity of $\mathrm{Ca}\left(\mathrm{NO}_{3}\right)_{2}$ than $\mathrm{CaSO}_{4}$, the formation of $\mathrm{Ca}\left(\mathrm{NO}_{3}\right)_{2}$ would significantly enhance the uptake of water (and other soluble gases), resulting in a positive feedback until all the calcium transformed to calcium nitrate (Formenti 
et al., 2011). This process may offer an explanation for the much larger increase in nitrate than that of sulfate on the mineral particles during the transport from Mt. Hua to Mt. Heng (Fig. 4). The enrichment of ammonium will be discussed in Sect. 3.2.3.

\subsubsection{Changes of mineral dust characteristics with atmospheric processing time}

In order to further investigate the evolution of the mineral dust, the atmospheric processing time of the air masses was calculated by the photochemical age ratio $-\log _{10}\left(\mathrm{NO}_{\mathrm{x}} / \mathrm{NO}_{\mathrm{y}}\right)$ (Kleinman et al., 2008), and then was related to the changes in water-soluble ions on the mineral dust particles. As illustrated in Fig. 5a, the photochemical age generally showed an upward trend during the dust event (from 19:00, 24 April to 08:00, 27 April, LT). The sudden decrease in the values of $-\log _{10}\left(\mathrm{NO}_{\mathrm{x}} / \mathrm{NO}_{\mathrm{y}}\right)$ was related to the changes of northerly wind to easterly wind (Fig. 2), which brought freshly emitted $\mathrm{NO}_{\mathrm{x}}$ from the incense burning in the nearby temples. The photochemical ages of the first three samples increased gradually, while the values of the sampleIII and sample-IV were similar (approximately 0.7).

The ratios of sulfate, nitrate and ammonium to the PM mass in the supermicron range are shown in Figs. 5b. These results indicate overall increases in the relative abundances of all three ions with the atmospheric processing time of the air parcels. During the time scale of the four samples, sulfate increased from 1.7 to $2.4 \%$, nitrate from 2.5 to $4.3 \%$, and ammonium from 0.2 to $1.2 \%$. The increased water-soluble ions could significantly enhance the solubility of mineral particles, thus affecting their lifetimes and cloud condensation nuclei (CCN) or ice nuclei (IC) activity. It is worth noting that the large increases in the abundance of the secondary ions in sample III and sample IV with similar photochemical age indicate the contribution of additional factor(s) to the formation of these ions.

Acidity is another important factor that affects the chemical and physical properties of aerosols (Jang et al., 2002). For Asian dust particles, calcium is the major cation. Therefore, the ratios of the sum of major anions to calcium in equivalence in the supermicron range particles were calculated to investigate the changes in acidity of the mineral particles with the atmospheric processing time of the air mass. As illustrated in Fig. 5c, evident acidification occurred with the aging of the air mass. The ratio increased from 0.48 in the first sample to 0.96 in the third sample and to 1.20 in the fourth sample.

\subsubsection{Ammonium enrichment and a conceptual model for dust evolution}

In our study, large enrichments in ammonium on supermicron range particles were observed at Mt. Heng. The results show an absence of coarse-mode ammonium at Mt. Hua
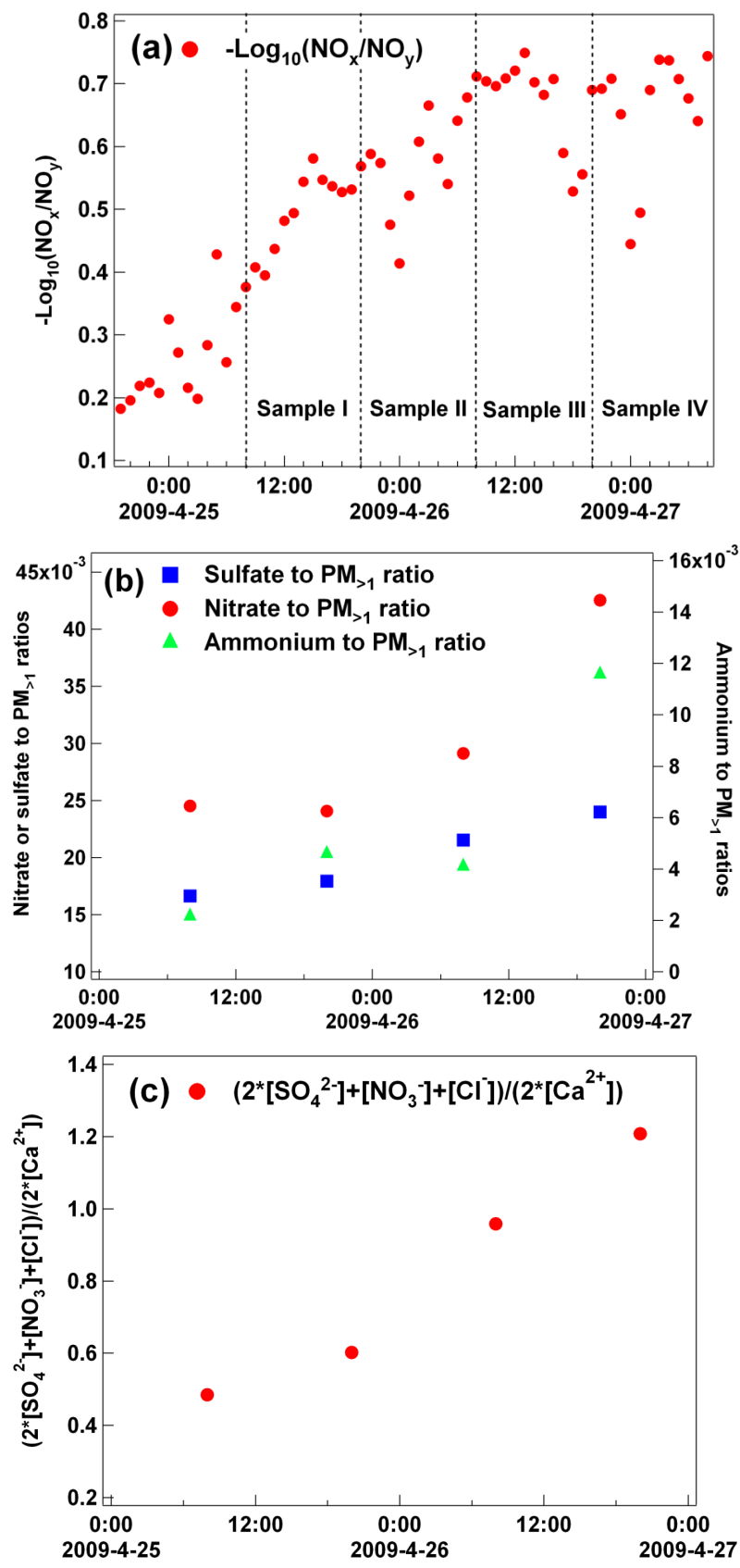

Fig. 5. (a) Photochemical age (defined as $-\log _{10}\left(\mathrm{NO}_{\mathrm{x}} / \mathrm{NO}_{\mathrm{y}}\right)$ ), (b) concentration ratios of sulfate, nitrate and ammonium to PM in the supermicron particles, (c) sum of major anions to calcium in equivalence in the supermicron particles, during the dust event on 24-26 April at Mt. Heng.

(Fig. 4c), an increase to a content of $2-5 \%$ in sample I to sample III, and a further increase to $\sim 12 \%$ in sample IV at Mt. Heng (Fig. 5c). These observations are in contrast to previous that which suggest suppression of the formation of ammonium aerosol by the invasion of a dust storm due to dilution of the precursor ammonia and the uptake of acidic gases on dust (Song and Carmichael, 1999; Huang et al., 2010). 


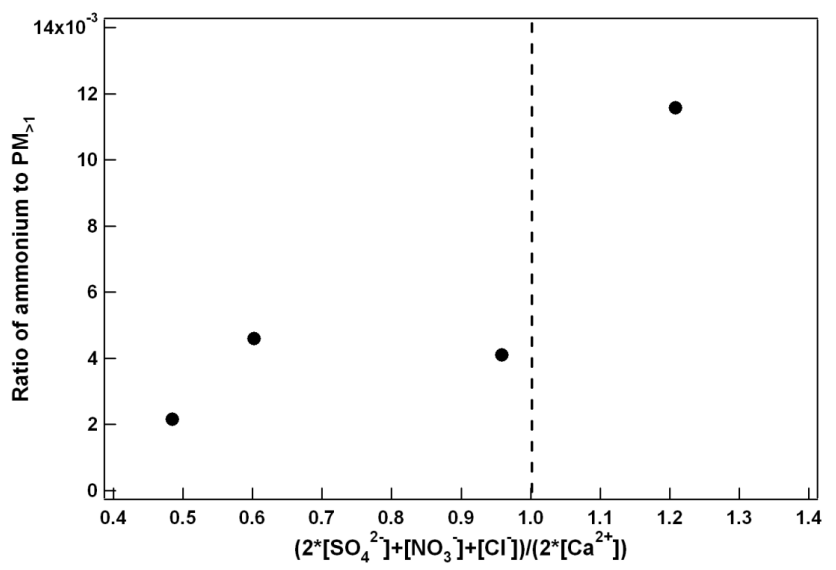

Fig. 6. Scatter plots of ratios of $\mathrm{NH}_{4}^{+} / \mathrm{PM}$ and $\left(2 \times\left[\mathrm{SO}_{4}^{2-}\right]+\left[\mathrm{NO}_{3}^{-}\right]+\left[\mathrm{Cl}^{-}\right]\right) /\left(2 \times\left[\mathrm{Ca}^{2+}\right]\right)$ in $\mathrm{PM}_{>1}$ during the dust event on 24-26 April at Mt. Heng.

Previous field observations have indicated that, for ammonium to form, mineral dust should first take up some acidic species that ammonia can partition to (Sullivan et al., 2007a). Carbonate-containing dust particles have a high alkalinity initially, and the uptake of secondary acids would first neutralize the alkaline carbonate and uptake of ammonia would follow. Thus some relationship between the amount of accumulated ammonium and the neutralized carbonate would be expected. In Asian dust, carbonates are mainly combined with calcium in the form of calcite (Matsuki et al., 2005). Figure 6 shows the relationship of ammonium abundances and the ratio of the sum of anions to calcium, which can be used to indicate the degree of neutralization of carbonate in the dust particles of Mt. Heng. It shows that the alkaline carbonates were not fully neutralized in the first three samples $\left(\left(2 \times\left[\mathrm{SO}_{4}^{2-}\right]+\left[\mathrm{NO}_{3}^{-}\right]+\left[\mathrm{Cl}^{-}\right]\right) /\left(2 \times\left[\mathrm{Ca}_{2}^{+}\right]\right)<1\right)$, but some ammonium was still observed in the supermicron mode. This observation can be explained as follows: after the depletion of surface carbonate, the absorbed acidic species would uptake the gas-phase ammonia in parallel with neutralizing the carbonate in the inner core. Then, after the carbonate was fully consumed, ammonium was enhanced significantly in the fourth sample (Fig. 6).

Based on the above discussions, a conceptual model is proposed to describe dust evolution into a four-stage process (Fig. 7): freshly emitted dust (stage 1), the uptake of secondary acidic species with little ammonium (stage 2, as represented by the sample of Mt. Hua; see Fig. 4c), dust with ammonium accumulated on but without the depletion of carbonate (stage 3, represented by sample-I to III of Mt. Heng; see Figs. 5c and 6), and dust with all carbonate neutralized and significantly enhanced ammonium (stage 4, represented by sample-IV of Mt. Heng). This 4-stage evolution has important implications for atmospheric chemistry and the impact of dust on climate. When the Asian dust particles have reached the third stage (i.e., with accumulated ammonium), the surface properties of the dust have changed from hydrophobic and alkaline to hydrophilic and acidic, thus significantly enhancing their CCN/IN capacity. At the fourth stage, the dust particles would be no different from the secondarily formed particles and could serve as favorable media to promote further reactions. It should be noted that the conceptual model can only apply to the carbonate-containing dust particles and that ambient ammonia concentrations will influence the development of the four stages.

\subsection{Photo-enhanced nitrite formation}

High nitrite concentrations on dust particles were observed during the dust event of 24-26 April. Figure 8 shows the nitrite concentrations in TSP in the four samples following the temporal order during the dust episode of 24-26 April. The average nitrite concentration during this dust event was $2.5 \mu \mathrm{g} \mathrm{m}^{-3}$, much higher than that during the non-dust days (the mean value $=0.3 \mu \mathrm{g} \mathrm{m}^{-3}$ ), indicating an enhancement of nitrite formation on the dust particles. Furthermore, the enhanced nitrite formation during the dust event occurred only in the daytime samples (with a concentration up to $6 \mu \mathrm{g} \mathrm{m}^{-3}$ in sample-III; see Fig. 8), suggesting a photochemical pathway yielding the observed nitrite.

Daytime HONO (as well as nitrite) can be produced from gas phase sources and photo-related heterogeneous sources (Kleffmann, 2007). The reaction of $\mathrm{NO}$ and $\mathrm{OH}$ radicals is the dominant gas phase process yielding HONO. However, due to the fast photolysis of HONO, it has been demonstrated that this reaction is not a net source and cannot explain the frequently observed high daytime HONO concentrations (e.g., Kleffmann, 2007; Sörgel et al., 2011). The insignificance of this gas-phase source in our study is supported by the low NO concentrations ( $<0.5 \mathrm{ppbv}$ ) observed during the dust event. Therefore, there must be other photo-related heterogeneous processes contributing to the observed daytime nitrite.

Heterogeneous photochemical reactions producing HONO are generally thought to occur via four different processes: the surface photolysis of nitric acid $\left(\mathrm{HNO}_{3}\right)$ (Zhou et al., 2003; Ramazan et al., 2004); photo-induced $\mathrm{NO}_{2}$ conversion on soot surfaces (Aubin and Abbatt, 2007); the heterogeneous photochemistry of $\mathrm{NO}_{2}$ on some organic surfaces, such as aromatic compounds and humic acids (George et al., 2005; Stemmler et al., 2006); and the surface $\mathrm{TiO}_{2}$ photocatalysis of $\mathrm{NO}_{2}$ (Gustafsson et al., 2006; Ndour et al., 2008). In order to determine the key process contributing to the observed nitrite formation, the concentrations of nitrite, nitrate and $\mathrm{BC}$ (representing soot) during the dust storm of 24-26 April were compared with those during a non-dust pollution episode (denoted as PE) occurring on 8-9 May (Table 2). Compared to those during $\mathrm{PE}$, the nitrate and $\mathrm{BC}$ concentrations during the dust storm were lower, but the nitrite concentrations were much higher. 


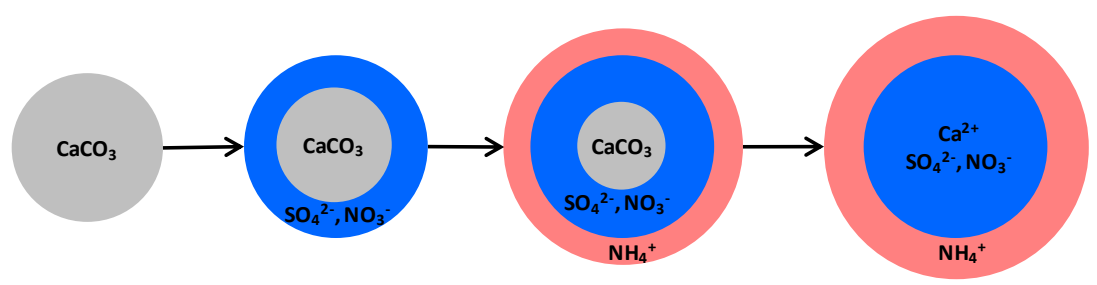

Fig. 7. Conceptual model showing the four aging stages for the carbonate-containing dust particles.

Table 2. Concentrations of nitrite in TSP, nitrate in TSP and BC in $\mathrm{PM}_{2.5}$ measured during the dust storm of 24-26 April and a nondust pollution episode that occurred on 8-9 May at Mt. Heng.

\begin{tabular}{lll}
\hline & $\begin{array}{l}\text { DS-II } \\
\text { on 25-26 April }\end{array}$ & $\begin{array}{l}\text { Pollution episode } \\
\text { on 8-9 May }\end{array}$ \\
\hline Nitrite in TSP $\left(\mu \mathrm{g} \mathrm{m}^{-3}\right)$ & 2.5 & 0.6 \\
Nitrate in TSP $\left(\mu \mathrm{g} \mathrm{m}^{-3}\right)$ & 15.6 & 20.1 \\
$\mathrm{BC}$ in $\mathrm{PM}_{2.5}\left(\mu \mathrm{g} \mathrm{m}^{-3}\right)$ & 3.2 & 3.5 \\
\hline
\end{tabular}

This result suggests that the first two reaction pathways were not the major contributors to the observed nitrite formation. Despite the fact that aromatic compounds and humic acids were not measured, their concentrations were not presumed to increase much during the dust storm because mineral dust particles are not their sources. Considering that the daytime enhancement of nitrite production was only observed in the dust storm event, the third process should also be excluded as the key contributor.

The fourth process of $\mathrm{TiO}_{2}$ photocatalysis of $\mathrm{NO}_{2}$ yielding HONO was recently demonstrated in the laboratory (Gustafsson et al., 2006; Ndour et al., 2008). The reaction mechanism can be simply described as nitrogen dioxides being reduced to nitrite ions by photo-produced electrons (the detailed mechanism was proposed in Ndour's study, 2008). In the present study, the titanium concentrations (in the form of $\mathrm{TiO}_{2}$, Chen et al., 2012) indeed increased significantly during the dust storm of 24-26 April (see Fig. 2), implying that the surface $\mathrm{TiO}_{2}$ photocatalysis may be responsible for the daytime nitrite formation. To further support this hypothesis, the correlations of daytime nitrite with titanium and with nitrate were also examined. Noting that the titanium concentration in the coarse mode particles $\left(\mathrm{PM}_{>2.5}\right)$ was unavailable, their values were calculated via the formula $\mathrm{Ti}_{\text {coarse }}=\mathrm{Ti}_{\text {fine }} \times\left(\mathrm{Al}_{\text {coarse }} / \mathrm{Al}_{\text {fine }}\right)$ under the assumption that aluminum and titanium have the same size distributions (Zhang et al., 2003). As tabulated in Table 3, for sample$\mathrm{I}$, the ratio of $\mathrm{NO}_{2}^{-}$(coarse) $/ \mathrm{NO}_{2}^{-}$(fine) was approximately 3.0, which was similar to that of titanium (approximately 2.8 ), but largely differed from that of nitrate (approximately 9.1). The result for sample-III was similar. These results further indicate the role of $\mathrm{TiO}_{2}$ photocatalysis on the observed daytime nitrite formation.
Table 3. Concentrations of titanium and nitrite in both fine particle mode $\left(\mathrm{PM}_{2.5}\right)$ and coarse particle mode $\left(\mathrm{PM}_{>2.5}\right)$ in the two daytime samples during the dust storm of 24-26 April at Mt. Heng.

\begin{tabular}{lcccccc}
\hline \multirow{2}{*}{ Sample } & \multicolumn{3}{c}{ Fine particles $\left(\mu \mathrm{g} \mathrm{m}^{-3}\right)$} & \multicolumn{4}{c}{ Coarse particles $\left(\mu \mathrm{g} \mathrm{m}^{-3}\right)$} \\
\cline { 2 - 7 } & $\mathrm{NO}_{2}^{-}$ & $\mathrm{Ti}$ & $\mathrm{NO}_{3}^{-}$ & $\mathrm{NO}_{2}^{-}$ & $\mathrm{Ti}^{*}$ & $\mathrm{NO}_{3}^{-}$ \\
\hline 04:25 Daytime & 0.68 & 0.58 & 2.0 & 2.02 & 1.61 & 18.2 \\
04:26 Daytime & 1.5 & 0.42 & 1.0 & 4.49 & 1.12 & 10.7 \\
\hline
\end{tabular}

* $\mathrm{Ti}$ in coarse particles was calculated by $\mathrm{Ti}_{\text {coarse }}=\mathrm{Ti}_{\text {fine }} \times\left(\mathrm{Al}_{\text {coarse }} / \mathrm{Al}_{\text {fine }}\right)$.

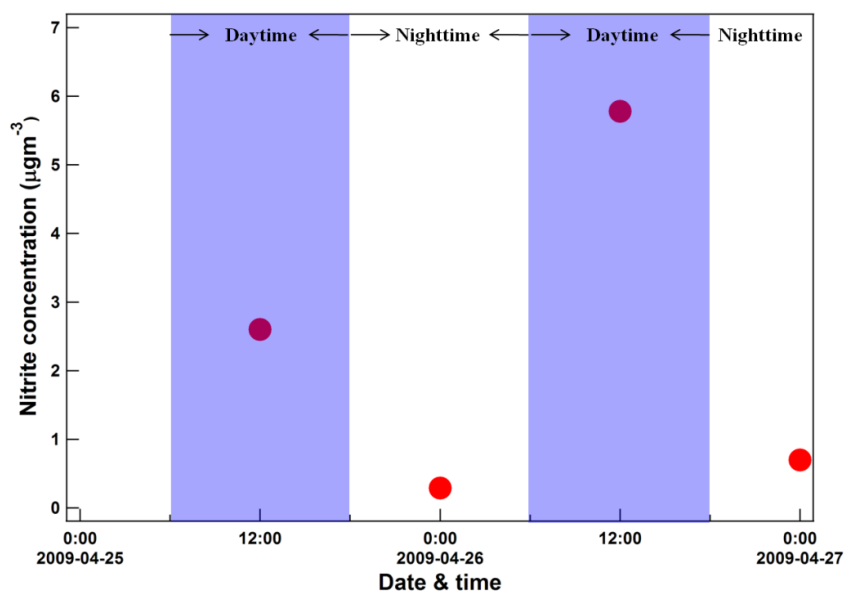

Fig. 8. Nitrite concentrations in TSP collected during the dust event on 24-26 April at Mt. Heng.

The partition between gas-phase HONO and aerosol nitrite is affected by acidity of dust particles. In the two daytime samples (sample-I and sample-III), the supermicron particles showed strong alkalinity (Fig. 5d). Under such a condition, the nitrous acid is normally thought to favor partitioning to the aerosol phase. However, Ndour et al. (2008) observed 2.3 ppbv of gas-phase $\mathrm{HONO}$ produced from $3 \mathrm{ppbv}$ of $\mathrm{NO}_{2}$ on irradiated real Sahara dust particles, suggesting the potential source of the gas-phase HONO from the heterogeneous photochemical reactions of dust particles even under the condition of strong alkalinity. In addition, the presence of coarse mode ammonium (samples I to III, the third stage, Fig. 7) may suggest the surface acidification of the dust particles, which would promote the partitioning of nitrous acid to the gas phase in samples I-III. For sample IV, strong acidity was 
indicated (the fourth-stage, Fig. 7); the newly formed daytime nitrous acid would mainly partition to the gas phase as HONO and therefore would significantly contribute to the radical pool during daytime.

In summary, photo-enhanced nitrite formation on dust particles was observed, which indicated lab-demonstrated $\mathrm{TiO}_{2}$ photocatalysis of $\mathrm{NO}_{2}$ as an important source of daytime HONO under dust storm conditions. Given that there is increasing evidence for anthropogenic sources of photocatalyst-containing (including $\mathrm{TiO}_{2}$ ) nanodusts emitted from industrial nanomaterials (Vicki, 2009; Chen et al., 2012), this process may play a potentially important role in atmospheric chemistry on a global scale. We therefore recommend more comprehensive studies to better evaluate the contribution of photoactive particles to gas-phase HONO and, in turn, $\mathrm{OH}$ radicals.

\section{Summary and conclusions}

An intense Asian dust storm that originated from the Gobi Desert was captured at a mountain site (Mount Heng) in southern China. The mineral dust particles experienced significant modifications before arriving at Mt. Heng, with large enrichments in secondary species, such as sulfate, nitrate and ammonium. The dust particles became more acidic and hydrophilic with the atmospheric processing time of air parcels. The accumulation of ammonium on dust particles was verified, which is related to the neutralization of carbonate. Based on the observations, a four-stage conceptual model is proposed to describe the aging process of the carbonate-rich Asian dust.

Photo-enhanced nitrite formation on the dust particles was also observed, indicating that the $\mathrm{TiO}_{2}$ photocatalysis of $\mathrm{NO}_{2}$ is a potentially important source of $\mathrm{HONO}$ (and nitrite) under dust storm conditions. In view of the potential for nanodust to become a global source of photocatalysts (e.g., $\mathrm{TiO}_{2}$ ), this process may be an important daytime HONO source. More studies are needed in order to examine further the extent of photo-enhanced nitrite formation in the atmosphere and its implications for atmospheric chemistry.

Acknowledgements. We thank Jia Guo, Weijun Li, Yuhua Li, Jie Zhou, Penghui Li and Minghu Sun for their contribution to the field work and data processing, and Kin Fai Ho and Hongmei Xu for their help on the elements analysis. We are grateful to the NOAA Air Resources Laboratory for providing the HYSPLIT model. This study was funded by the National Basic Research Program of China (2005CB422203) and the Niche Area Development Program of the Hong Kong Polytechnic University (1-BB94).

Edited by: Y.-S. Chung

\section{References}

Arimoto, R., Kim, Y. J., Kim, Y. P., Quinn, P. K., Bates, T. S., Anderson, T. L., Gong, S., Uno, I., Chin, M., Huebert, B. J., Clarke, A. D., Shinozuka, Y., Weber, R. J., Anderson, J. R., Guazzotti, S. A., Sullivan, R. C., Sodeman, D. A., Prather, K. A., and Sokolik, I. N.: Characterization of Asian Dust during ACE-Asia, Global Planet. Change, 52, 23-56, 2006.

Aubin, D. G. and Abbatt, J. P. D.: Interaction of $\mathrm{NO}_{2}$ with Hydrocarbon Soot:? Focus on HONO Yield, Surface Modification, and Mechanism, J. Phys. Chem. A, 111, 6263-6273, 2007.

Chen, H., Nanayakkara, C. E., and Grassian, V. H.: Titanium Dioxide Photocatalysis in Atmospheric Chemistry, Chem. Rev., 112, 5919-5948, doi:10.1021/cr3002092, 2012.

Cwiertny, D. M., Young, M. A., and Grassian, V. H.: Chemistry and photochemistry of mineral dust aerosol, Annu. Rev. Phys. Chem., 59, 27-51, 2008.

Formenti, P., Schütz, L., Balkanski, Y., Desboeufs, K., Ebert, M., Kandler, K., Petzold, A., Scheuvens, D., Weinbruch, S., and Zhang, D.: Recent progress in understanding physical and chemical properties of African and Asian mineral dust, Atmos. Chem. Phys., 11, 8231-8256, doi:10.5194/acp-11-8231-2011, 2011.

Gao, X., Xue, L., Wang, X., Wang, T., Yuan, C., Gao, R., Zhou, Y., Nie, W., Zhang, Q., and Wang, W.: Aerosol ionic components at Mt. Heng in central southern China: Abundances, size distribution, and impacts of long-range transport, Sci. Total Environ., 433, 498-506, doi:10.1016/j.scitotenv.2012.06.095, 2012.

George, C., Strekowski, R. S., Kleffmann, J., Stemmler, K., and Ammann, M.: Photoenhanced uptake of gaseous $\mathrm{NO}_{2}$ on solid organic compounds: a photochemical source of HONO?, Faraday Discuss., 130, 195-210, 2005.

Gustafsson, R. J., Orlov, A., Griffiths, P. T., Cox, R. A., and Lambert, R. M.: Reduction of $\mathrm{NO}_{2}$ to nitrous acid on illuminated titanium dioxide aerosol surfaces: implications for photocatalysis and atmospheric chemistry, Chem. Commun., 3936-3938, 2006.

Huang, K., Zhuang, G., Li, J., Wang, Q., Sun, Y., Lin, Y., and $\mathrm{Fu}$, J. S.: Mixing of Asian dust with pollution aerosol and the transformation of aerosol components during the dust storm over China in spring 2007, J. Geophys. Res., 115, D00K13, doi:10.1029/2009jd013145, 2010.

Jacob, D. J., Crawford, J. H., Kleb, M. M., Connors, V. S., Bendura, R. J., Raper, J. L., Sachse, G. W., Gille, J. C., Emmons, L., and Heald, C. L.: Transport and Chemical Evolution over the Pacific (TRACE-P) aircraft mission: Design, execution, and first results, J. Geophys. Res., 108, 9000, doi:10.1029/2002jd003276, 2003.

Jang, M., Czoschke, N. M., Lee, S., and Kamens, R. M.: Heterogeneous Atmospheric Aerosol Production by Acid-Catalyzed Particle-Phase Reactions, Science, 298, 814-817, 2002.

Kleffmann, J.: Daytime Sources of Nitrous Acid (HONO) in the Atmospheric Boundary Layer, Chem. Phys. Chem., 8, 1137-1144, 2007.

Kleinman, L. I., Springston, S. R., Daum, P. H., Lee, Y.-N., Nunnermacker, L. J., Senum, G. I., Wang, J., Weinstein-Lloyd, J., Alexander, M. L., Hubbe, J., Ortega, J., Canagaratna, M. R., and Jayne, J.: The time evolution of aerosol composition over the Mexico City plateau, Atmos. Chem. Phys., 8, 1559-1575, doi:10.5194/acp-8-1559-2008, 2008.

Laurent, B., Marticorena, B., Bergametti, G., and Mei, F.: Modeling mineral dust emissions from Chinese and Mongolian deserts, Global Planet. Change, 52, 121-141, 2006. 
Li, W. J. and Shao, L. Y.: Observation of nitrate coatings on atmospheric mineral dust particles, Atmos. Chem. Phys., 9, 18631871, doi:10.5194/acp-9-1863-2009, 2009.

Matsuki, A., Iwasaka, Y., Shi, G. Y., Chen, H. B., Osada, K., Zhang, D., Kido, M., Inomata, Y., Kim, Y. S., Trochkine, D., Nishita, C., Yamada, M., Nagatani, T., Nagatani, M., and Nakata, H.: Heterogeneous sulfate formation on dust surface and its dependence on mineralogy: Balloon-borne observations from ballon-borne measurements in the surface of Beijing, China, Water Air Soil Poll., 5, 101-132, 2005.

Ndour, M., D’Anna, B., George, C., Ka, O., Balkanski, Y., Kleffmann, J., Stemmler, K., and Ammann, M.: Photoenhanced uptake of $\mathrm{NO}_{2}$ on mineral dust: Laboratory experiments and model simulations, Geophys. Res. Lett., 35, L05812, doi:10.1029/2007g1032006, 2008.

Nicolas, M. L., Ndour, M., Ka, O., D’Anna, B., and George, C.: Photochemistry of Atmospheric Dust: Ozone Decomposition on Illuminated Titanium Dioxide, Environ. Sci. Technol., 43, 74377442, 2009.

Nie, W., Wang, T., Gao, X., Pathak, R. K., Wang, X., Gao, R., Zhang, Q., Yang, L., and Wang, W.: Comparison among filterbased, impactor-based and continuous techniques for measuring atmospheric fine sulfate and nitrate, Atmos. Environ., 44, 43964403, 2010.

Ramazan, K. A., Syomin, D., and Finlayson-Pitts, B. J.: The photochemical production of $\mathrm{HONO}$ during the heterogeneous hydrolysis of $\mathrm{NO}_{2}$, Phys. Chem. Chem. Phys, 6, 3836-3843, 2004.

Singh, H. B., Brune, W. H., Crawford, J. H., Flocke, F., and Jacob, D. J.: Chemistry and transport of pollution over the Gulf of Mexico and the Pacific: spring 2006 INTEX-B campaign overview and first results, Atmos. Chem. Phys., 9, 2301-2318, doi:10.5194/acp-9-2301-2009, 2009.

Song, C. H. and Carmichael, G. R.: The aging process of naturally emitted aerosol (sea-salt and mineral aerosol) during long range transport, Atmos. Environ., 33, 2203-2218, 1999.

Sörgel, M., Regelin, E., Bozem, H., Diesch, J.-M., Drewnick, F., Fischer, H., Harder, H., Held, A., Hosaynali-Beygi, Z., Martinez, M., and Zetzsch, C.: Quantification of the unknown HONO daytime source and its relation to $\mathrm{NO}_{2}$, Atmos. Chem. Phys., 11, 10433-10447, doi:10.5194/acp-11-10433-2011, 2011.

Stemmler, K., Ammann, M., Donders, C., Kleffmann, J., and George, C.: Photosensitized reduction of nitrogen dioxide on humic acid as a source of nitrous acid, Nature, 440, 195-198, 2006.

Sullivan, R. C. and Prather, K. A.: Investigations of the diurnal cycle and mixing state of oxalic acid in individual particles in Asian aerosol outflow, Environ. Sci. Technol., 41, 8062-8069, 2007.

Sullivan, R. C., Guazzotti, S. A., Sodeman, D. A., and Prather, K. A.: Direct observations of the atmospheric processing of Asian mineral dust, Atmos. Chem. Phys., 7, 1213-1236, doi:10.5194/acp-7-1213-2007, 2007a.

Sullivan, R. C., Guazzotti, S. A., Sodeman, D. A., Tang, Y., Carmichael, G. R., and Prather, K. A.: Mineral dust is a sink for chlorine in the marine boundary layer, Atmos. Environ., 41, 7166-7179, 2007b.

Sun, M., Wang, Y., Wang, T., Fan, S., Wang, W., Li, P., Guo, J., and Li, Y.: Cloud and the corresponding precipitation chemistry in south China: Water-soluble components and pollution transport, J. Geophys. Res., 115, D22303, doi:10.1029/2010jd014315, 2010 .
Usher, C. R., Michel, A. E., and Grassian, V. H.: Reactions on mineral dust, Chem. Rev., 103, 4883-4939, 2003.

Vecchi, R., Chiari, M., D’Alessandro, A., Fermo, P., Lucarelli, F., Mazzei, F., Nava, S., Piazzalunga, A., Prati, P., Silvani, F., and Valli, G.: A mass closure and PMF source apportionment study on the sub-micron sized aerosol fraction at urban sites in Italy, Atmos. Environ., 42, 2240-2253, doi:10.1016/j.atmosenv.2007.11.039, 2008.

Vicki, H. G.: New Directions: Nanodust - A source of metals in the atmospheric environment?, Atmos. Environ., 43, 4666-4667, 2009.

Wang, G., Li, J., Cheng, C., Hu, S., Xie, M., Gao, S., Zhou, B., Dai, W., Cao, J., and An, Z.: Observation of atmospheric aerosols at Mt. Hua and Mt. Tai in central and east China during spring 2009 - Part 1: EC, OC and inorganic ions, Atmos. Chem. Phys., 11, 4221-4235, doi:10.5194/acp-11-4221-2011, 2011.

Wang, T., Cheung, V. T. F., Anson, M., and Li, Y. S.: Ozone and related gaseous pollutants in the boundary layer of eastern China: Overview of the recent measurements at a rural site, Geophys. Res. Lett., 28, 2373-2376, 2001.

Wang, T., Ding, A. J., Blake, D. R., Zahorowski, W., Poon, C. N., and Li, Y. S.: Chemical characterization of the boundary layer outflow of air pollution to Hong Kong during February-April 2001, J. Geophys. Res., 108, 8787, doi:10.1029/2002jd003272, 2003.

Wang, T., Wei, X. L., Ding, A. J., Poon, C. N., Lam, K. S., Li, Y. S., Chan, L. Y., and Anson, M.: Increasing surface ozone concentrations in the background atmosphere of Southern China, 19942007, Atmos. Chem. Phys., 9, 6217-6227, doi:10.5194/acp-96217-2009, 2009.

Wang, T., Nie, W., Gao, J., Xue, L. K., Gao, X. M., Wang, X. F., Qiu, J., Poon, C. N., Meinardi, S., Blake, D., Wang, S. L., Ding, A. J., Chai, F. H., Zhang, Q. Z., and Wang, W. X.: Air quality during the 2008 Beijing Olympics: secondary pollutants and regional impact, Atmos. Chem. Phys., 10, 7603-7615, doi:10.5194/acp10-7603-2010, 2010.

Wang, Y., Sun, M., Li, P., Li, Y., Xue, L., and Wang, W.: Variation of low molecular weight organic acids in precipitation and cloudwater at high elevation in South China, Atmos. Environ., 45, 6518-6525, 2011.

Wu, W. S. and Wang, T.: On the performance of a semi-continuous $\mathrm{PM}_{2.5}$ sulphate and nitrate instrument under high loadings of particulate and sulphur dioxide, Atmos. Environ., 41, 54425451, 2007.

Zhang, X. Y., Gong, S. L., Arimoto, R., Shen, Z. X., Mei, F. M., Wang, D., and Cheng, Y.: Characterization and Temporal Variation of Asian Dust Aerosol from a Site in the Northern Chinese Deserts, J. Atmos. Chem., 44, 241-257, doi:10.1023/a:1022900220357, 2003.

Zhou, S., Wang, Z., Gao, R., Xue, L., Yuan, C., Wang, T., Gao, X., Wang, X., Nie, W., Xu, Z., Zhang, Q., and Wang, W.: Formation of secondary organic carbon and long-range transport of carbonaceous aerosols at Mount Heng in South China, Atmos. Environ., 63, 203-212, doi:10.1016/j.atmosenv.2012.09.021, 2012.

Zhou, X., Gao, H., He, Y., Huang, G., Bertman, S. B., Civerolo, K., and Schwab, J.: Nitric acid photolysis on surfaces in low$\mathrm{NO}_{\mathrm{x}}$ environments: Significant atmospheric implications, Geophys. Res. Lett., 30, 2217, doi:10.1029/2003gl018620, 2003. 
Zhou, Y., Wang, T., Gao, X., Xue, L., Wang, X., Wang, Z., Gao, J., Zhang, Q., and Wang, W.: Continuous observations of water-soluble ions in $\mathrm{PM}_{2.5}$ at Mount Tai (1534 m.a.s.1.) in central-eastern China, J. Atmos. Chem., 64, 107-127, doi:10.1007/s10874-010-9172-z, 2009.
Zhuang, G., Yi, Z., Duce, R. A., and Brown, P. R.: Link between iron and sulphur cycles suggested by detection of $\mathrm{Fe}(\mathrm{n})$ in remote marine aerosols, Nature, 355, 537-539, 1992. 